Terakreditasi: SK No.: 60/E/KPT/2016

Website : http://ejournal.undip.ac.id/index.php/reaktor/

Reaktor, Vol. 16 No. 4, Desember Tahun 2016, Hal. 207-211

\title{
A Comparative Study of Yarn Dyed Wastewater Using Fenton's Reagent and Ozonation : Removal Efficiency and Economic Analysis
}

\author{
Lieke Riadi ${ }^{1,2 *}$, Richard Wisanto ${ }^{1)}$, Arief Rachmat Herlambang1), \\ Sasmita Mirifica Vania ${ }^{1)}$, and Andy Widyasayogo ${ }^{1)}$ \\ ${ }^{1)}$ Department of Chemical Engineering, The University of Surabaya \\ ${ }^{2)}$ Center for Environmental Studies, The University of Surabaya \\ Jl. Raya Kalirungkut Surabaya \\ Telp./Fax. (031)2981158/(031)2981387 \\ ${ }^{*}$ Corresponding author: lieke@staff.ubaya.ac.id
}

\begin{abstract}
This study makes a comparison between Fenton and Ozonation processes treatment methods to examine the removal of COD in yarn dyed wastewater with initial concentration of 525 ppm. Results indicated that the COD degradation efficiency was in order of Fenton > Ozone. In Fenton method, the ratio of $\mathrm{Fe}^{2+} / \mathrm{H}_{2} \mathrm{O}_{2}$ used was 1:10, the concentration of $\mathrm{H}_{2} \mathrm{O}_{2}$ was $10.2 \mathrm{gram} / \mathrm{L}$. In ozonation, the ozone concentration used in the study was $5.8 \% \mathrm{~mol}$, and the agitation was $400 \mathrm{rpm}$. The effect of operational parameters including, initial $\mathrm{pH}$ and time were studied in both processes. The results indicated that it was $86.2 \%$ COD were removed, when the $p H$ was about 3 using Fenton's reagent and $83.06 \%$ COD removal in ozonation for one hour experiment. To achieve the standard requirement for allowable parameters in wastewater to be discharged, there is only 15 minutes needed for Fenton process to remove COD by $84.8 \%$, while the ozonation needs 30 minutes for $81 \%$ removal. Fenton process is more economic feasible compare to ozonation which is almost one-tenth of the operation cost for 1 liter of wastewater being process. Though both processes can demonstrate the high removal efficiency to achieve the allowable COD concentration in the wastewater to be discharged, Fenton process is favor to ozonation.
\end{abstract}

Keywords: fenton; ozonation; removal of COD; yarn dyed wastewater

\section{Abstrak}

STUDI PERBANDINGAN AIR LIMBAH PEWARNA BENANG MENGGUNAKAN REAGEN FENTON DAN OZONASI: EFFISIENSI PENGHILANGAN WARNA DAN ANALISA EKONOMI. Studi perbandingan pengolahan limbah dengan menggunakan metode fenton dan ozonasi ini dilakukan untuk mengkaji penghilangan COD di limbah pewarnaan benang dengan konsentrasi COD mula mula 525 ppm. Hasil penelitian menunjukkan bahwa efisiensi degradasi COD berada pada urutan metode Fenton lebih baik dari pada Ozonasi.Pada metode Fenton, perbandingan $\mathrm{Fe}^{2+} / \mathrm{H}_{2} \mathrm{O}_{2}$ yang digunakan adalah 1:10, dan konsentrasi $\mathrm{H}_{2} \mathrm{O}_{2}$ sebesar 10,2 gram/L. Pada ozonasi, konsentrasi ozon yang digunakan adalah 5,8\% mol dengan agitasi $400 \mathrm{rpm}$. Efek parameter operasional yaitu $\mathrm{pH}$ dan waktu dipelajari dalam penelitian ini.Hasil penelitian menunjukkan bahwa 86,2\% COD berhasil dihilangkan ketika digunakan $\mathrm{pH}=3.0$ untuk metode Fenton, dan 83,06\% COD dapat dihilangkan dengan ozonasi selama 1 jam. Untuk memenuhi standar baku mutu pembuangan air limbah, waktu yang dibutuhkan hanya 15 menit untuk menghilangkan 84,8\% COD dengan metode 
Fenton, sedangkan ozonasi membutuhkan 30 menit untuk mencapai 81\% penghilangan COD. Proses Fenton lebih ekonomis dibandingkan ozonasi dengan biaya operasi hampir 1/10 dari biaya ozonasi untuk 1 liter limbah. Proses Fenton lebih disukai daripada ozonasi karena aspek ekonomi, walaupun kedua metode ini mamapu menurunkan kadar COD sampai batas ambang yang diijinkan.

Kata kunci: fenton; ozonasi; penghilangan COD; limbah pewarnaan benang

How to Cite This Article: Riadi, L., Wisanto, R., Herlambang, A.R., Vania, S.M., and Widyasayogo, A., (2016), A Comparative Study of Yarn Dyed Wastewater Using Fenton's Reagent and Ozonation: Removal Efficiency and Economic Analysis, Reaktor, 16(4), 207-211, http://dx.doi.org/10.14710/reaktor.16.4.207-211

\section{INTRODUCTION}

Yarn dyed wastewater is one of recalcitrant wastewater and it is one of highly toxic wastewater. The wastewater is characterized by the parameters of biological oxygen demand (BOD), chemical oxygen demand (COD), $\mathrm{pH}$, suspended solids and color. Some of these parameters are removed by coagulation but failed to be treated biologically since the ratio of COD to $\mathrm{BOD}$ is more than 6.0. Advanced oxidation processes including $\mathrm{UV} / \mathrm{H}_{2} \mathrm{O}_{2}, \mathrm{TiO}_{2} / \mathrm{UV}$, photofenton, fenton's reagent and ozonation have been tried to treat such wastewater (Modirshahla et al., 2007; Khataee et al., 2009; Baban et al., 2003; Gunten, 2003; Georgiou et al., 2003).

Dyes present in wastewater are of particular environmental concern since the presence of color in water and also the harmful compounds in the dyes are carcinogen and mutagenic which can cause severe dysfunctional of brain and nerve systems (Kadirelu et al., 2003). Advanced oxidation processes are based on the generation of hydroxyl radicals $(\cdot \mathrm{OH})$ which degrade organic pollutants quickly (Khataee et al., 2009). The organic matter (OM) in the solution are oxidized by hydroxyl radical as soon as $\bullet \mathrm{OH}$ is generated, as described in the following equation:

$\cdot \mathrm{OH}+\mathrm{OM} \rightarrow$ intermediates $\rightarrow$ harmless species such as $\mathrm{CO}_{2}, \mathrm{H}_{2} \mathrm{O}$, etc.

We have conducted two AOPs in this study which were using Fenton'reagent and ozonation. Fenton's reagent is a mixture of ferrous ion $\left(\mathrm{Fe}^{2+}\right)$ and hydrogen peroxide $\left(\mathrm{H}_{2} \mathrm{O}_{2}\right)$ generating hydroxyl radical $(\bullet \mathrm{OH})$ according to the following equation:

$$
\mathrm{Fe}^{2+}+\mathrm{H}_{2} \mathrm{O}_{2} \rightarrow \mathrm{Fe}^{3+}+\mathrm{OH}^{-}+\cdot \mathrm{OH}
$$

$\mathrm{Fe}(\mathrm{III})$ which was being produced, can catalyze the decomposition of $\mathrm{H}_{2} \mathrm{O}_{2}$. The reaction of $\mathrm{H}_{2} \mathrm{O}_{2}$ with $\mathrm{Fe}$ (III) (so called the Fenton's-like reagent) goes through the formation of hydroperoxyl radical $\mathrm{HO}_{2}$ • (Ensing et al., 2003):

$$
\mathrm{Fe}^{3+}+\mathrm{H}_{2} \mathrm{O}_{2} \rightarrow \mathrm{Fe}^{2+}+\mathrm{HO}_{2} \bullet+\mathrm{H}^{+}
$$

As peroxide is available in the system, the cycle of $\mathrm{Fe}^{2+}$ and $\mathrm{Fe}^{3+}$ is continue. Ozonation is another AOP that we also used in this study. Ozone is able to react with organic matter due to its reactivity. The free radicals come from reaction mechanisms of ozone decomposition in water due to hydroxyl ion as shown as follows:

$$
\begin{gathered}
\mathrm{O}_{3}+\mathrm{OH}^{-} \stackrel{\mathrm{k}=70 \mathrm{M}^{-1} \mathrm{~s}^{-1}}{\longrightarrow} \mathrm{HO}_{2}^{-}+\mathrm{O}_{2} \\
\mathrm{O}_{3}+\mathrm{HO}_{2} \bullet \stackrel{\mathrm{k}=2 \times 10^{6} \mathrm{M}^{-1} \mathrm{~s}^{-1}}{\longrightarrow} \mathrm{HO}_{2} \bullet+\mathrm{O}_{2} \bullet
\end{gathered}
$$

Reactions (4) and (5) are important because these are the initiating steps of the radical mechanism leading to the formation of hydroxyl radicals when ozone decomposes (Tarr, 2003).

The wastewater used in this study was previously treated using electrocoagulation to remove suspendend solid and color. The wastewater then treated using AOPs namely fenton's reagent and ozonation separately. The aim of this study is to compare the efficiency of COD removal using both methods and also to analyse the economic feasibility. The effect of initial $\mathrm{pH}$ and time were also studied. The Fenton's method has been implemented in the real yarn dyed wastewater with capacity of $15 \mathrm{~m}^{3}$ wastewater/day. The economic analysis was used as a decision to choose fenton's method rather than ozonation.

\section{MATERIALS AND METHODS}

\section{The Characteristic of Wastewater}

The wastewater was collected from a yarn dye manufacturing located in South of Surabaya city, East Java Province, Indonesia. The wastewater has characteristic of COD $850 \mathrm{ppm}$, TSS (Total Suspended Solid) $4200 \mathrm{ppm}$, BOD 100 ppm, color $1.66 \mathrm{~cm}^{-1}$ and $\mathrm{pH} 10.6$. After electrocoagulation, the characteristic of wastewater can be seen in Table 1 .

\begin{tabular}{ccc}
\multicolumn{3}{c}{ Table 1. Characteristic of wastewater prior AOP } \\
\hline Parameters & Unit & After coagulation \\
\hline COD & ppm & 525.28 \\
BOD & ppm & 80 \\
TSS & ppm & 2100 \\
pH & - & 7.5 \\
color & $\mathrm{cm}^{-1}$ & 0.124 \\
\hline
\end{tabular}

\section{Fenton Process}

The wastewater after treated by electrocoagulation was then treated in a $1.5 \mathrm{~L}$ glass reactor equipped with stirrer and cooling jacket to maintain the experiment at room temperature. The chemicals used in the process were hydrogen peroxide and $\mathrm{FeSO}_{4} \cdot 7 \mathrm{H}_{2} \mathrm{O}$. The operating conditions were set at the best condition as follows: ratio of $\mathrm{Fe}^{2+} / \mathrm{H}_{2} \mathrm{O}_{2}$ 1:10, 
initial $\mathrm{pH} 3.0$ and dosage of $\mathrm{H}_{2} \mathrm{O}_{2}$ was 10.2 gram/L (Riadi et al., 2016). Samples were withdrawn periodically up to 90 minutes of experiment. All samples from fenton oxidation process were measured for COD content. The equipment used can be seen in Figure 1.

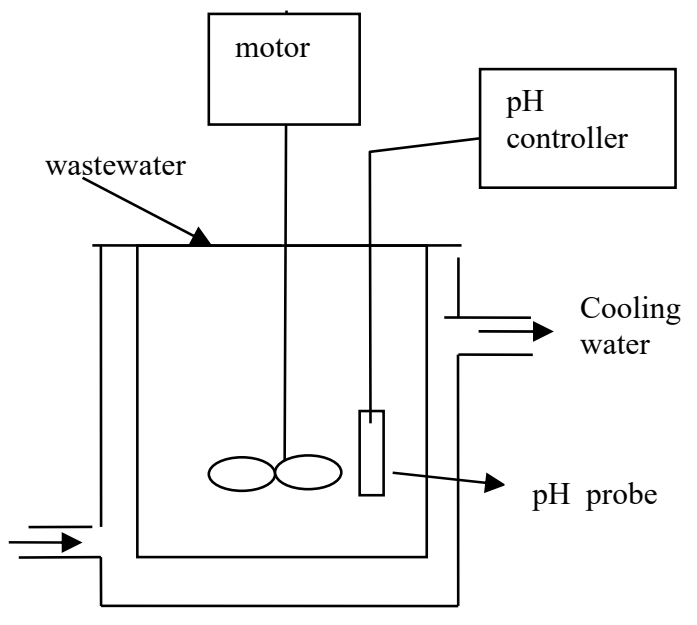

Figure1. Fenton process in batch system

\section{Ozonation}

The wastewater was fed to a $1.5 \mathrm{~L}$ stainless steel reactor equipped with stirrer, sparger, thermocouple and cooling jacket which was used for the experiment. The cooling jacket was used to maintain the experiment at $25^{\circ} \mathrm{C}$. The equipment used in the experiment can be seen in Figure 2. Ozone was generated from oxygen by ozone generator. The exit port of ozone generator is connected with deep tube and the ozone gas is delivered to the reactor through tube sparger at the bottom. The agitation was done at $400 \mathrm{rpm}$ with the ozone concentration of $5.8 \% \mathrm{~mol}$. Samples were withdrawn periodically up to 60 minutes of experiment, and aerated for 5 minutes to remove residual ozone (Selcuk, 2005). The ozone trapped in a $\mathrm{KI}$ in container to prevent the loss of ozone to the environment.

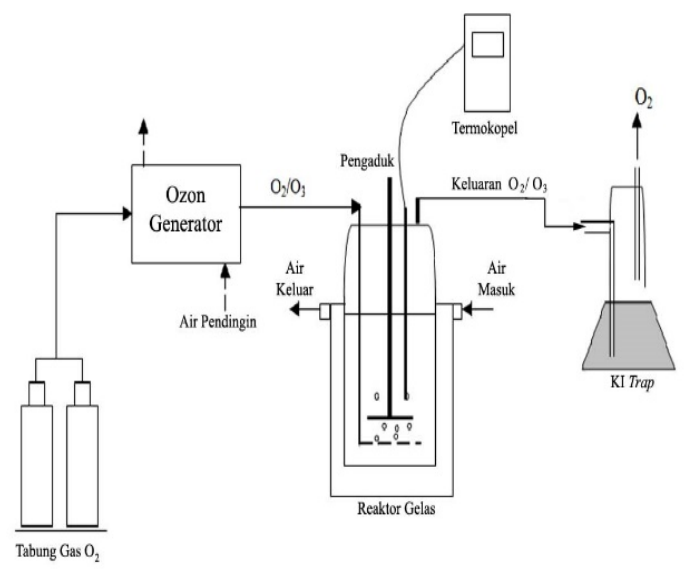

Figure 2. Ozonation process
Assay

Chemical oxygen demand was measured using closed reflux, colorimetric method (APHA, 1998). Total Suspended solid was measured using dried method based on a method from APHA, color measurement was conducted using UV-Vis spectrophotometer at $498 \mathrm{~nm}$ wavelength (APHA, 1998). The BOD (biological oxygen demand) was measured by respirometer using BOD system BD600, Lovibond. The percentage of COD removal was calculated as (initial COD concentration-final COD concentration)/(initial COD concentration) $\}$ x 100\%.

\section{RESULTS AND DISCUSSION \\ Effect of pH}

Effect of initial $\mathrm{pH}$ in wastewater was studied both in fenton process and ozonation. Initial $\mathrm{pH}$ of wastewater usually has a big influence on dye degradation (Zaied et al., 2011). Fenton process perform better at lower $\mathrm{pH}$ since the production of hydroxyl radicals is influenced by $\mathrm{pH}$ (Qiao et al., 2005). Result from the experiment is similar to a review reported by Wang et al. (2016). Figure 3 illustrates the effect of $\mathrm{pH}$ in fenton process and ozonation. In higher $\mathrm{pH}(\mathrm{pH}>3.0)$ the hydrolysis and precipitation of $\mathrm{Fe}^{3+}$ in the liquid phase can reduce the capacity of the the catalyst itself (Fassi et al., 2014). There is not much different in COD removal at different $\mathrm{pH}$ in ozonation. Lower $\mathrm{pH}(\mathrm{pH}<7)$ can give a better result for COD removal since at higher $\mathrm{pH}(\mathrm{pH}>7.0)$, ozone can be decomposed (Peleg, 1976). However, we found that the reduction of COD is not much different at $\mathrm{pH}=5.0$ compare to that at $\mathrm{pH}=7.0$ in ozonation process. So, the experiment at $\mathrm{pH}=3.0$ was not carried out.

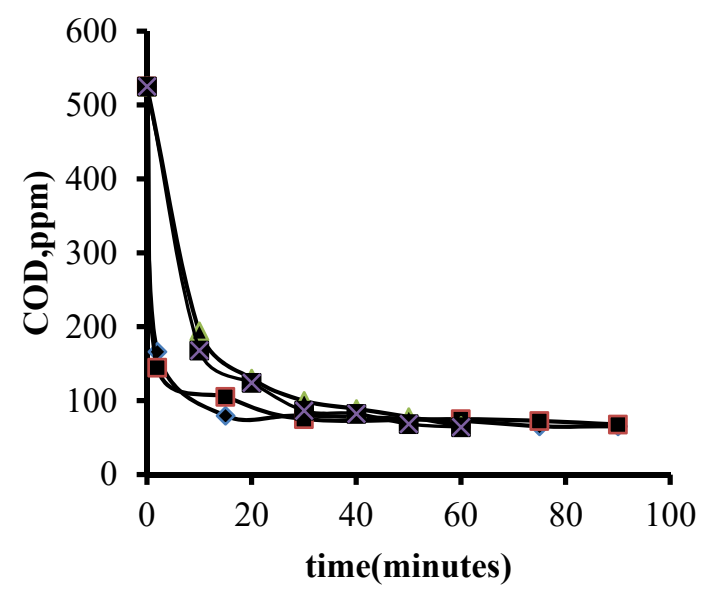

Figure 3. COD profile at different initial $\mathrm{pH}$ in fenton process $(\diamond=\mathrm{pH} 3.0 ; \mathbf{m}=\mathrm{pH} 5.0)$ and ozonation $(\boldsymbol{\Delta}=\mathrm{pH}=7.0 ; \mathrm{X}=\mathrm{pH}=5.0)$.

The experiments for the fenton were conducted at $\mathrm{pH}=3.0$ and $\mathrm{pH}=5.0$ as described above. However, there will be a strong scavenging effect of hydroxyl radical by $\mathrm{H}^{+}$, if the $\mathrm{pH}$ is too low $(<2.50)$ which decribes by reaction below: 


$$
\mathrm{HO}^{-}+\mathrm{H}^{+}+\mathrm{e}^{-} \rightarrow \mathrm{H}_{2} \mathrm{O}
$$

Hence, we don't work in higher $\mathrm{pH}$ for Fenton process $(\mathrm{pH}=7.0)$ and also at low $\mathrm{pH}(\mathrm{pH}=2.5)$. So, for Fenton process, we favor to work at $\mathrm{pH}=3.0$, whereas in ozonation we favor to work at neutral $\mathrm{pH}$.

\section{Effect of Time in Removal of COD}

The removal of COD in both processes were obvious. Fenton process resulted in a better of COD removal efficiency as can be seen in Table 2. The better percentage of COD removal in Fenton process is due to the standard redox potential of hydroxyl radical is $2.80 \mathrm{~V}$, which is higher than ozone $(2.07 \mathrm{~V})$.

Table 2. Removal overall efficiency at different initial $\mathrm{pH}$ for one hour experiment

\begin{tabular}{llll}
\hline & $\mathrm{pH}=3.0$ & $\mathrm{pH}=5.0$ & $\mathrm{pH}=7.0$ \\
\hline $\begin{array}{l}\text { Fenton } \\
\text { process }\end{array}$ & $86.2 \%$ & $85.7 \%$ & $\mathrm{n} / \mathrm{a}$ \\
Ozonation & $\mathrm{n} / \mathrm{a}$ & $84.9 \%$ & $83.06 \%$ \\
\hline
\end{tabular}

Though the reduction potential of hydroxyl ions is higher than ozone, the value for overall removal efficiency of both processes were not big different (see Table 2 at $\mathrm{pH}=5.0$ ). The significant different in percentage removal of COD is at the first 10 minutes of reaction, Fenton process gave a spontaneous reaction to degrade COD content, while ozonation gave a fast reaction. The removal of COD at the first 2 minutes experiment in Fenton process was $68.3 \%$, meanwhile the removal of COD at the first 10 minutes experiment of ozonation was $63.07 \%$. This phenomena indicates that redox potential of hydroxyl ion in fenton process is stronger than that in ozone which may degrade the COD faster. There is only 15 minutes needed to remove COD by $84.8 \%$ in Fenton process in order to achieve the standard requirement of COD in wastewater to be discharged (150 ppm COD). On the other hand, there is 30 minutes needed in timelength for ozonation to remove COD for the same purpose which is $81 \%$ removal. To have an objective comparison of both system performance, we need to also analyse both processes from economic point of view.

\section{Economic Analysis}

Economic analysis for both processes will be focused on operation cost and examined using one hour experiment time and removal of COD. By neglecting the electricity used for both reactors, the operation cost for fenton will include the cost for chemicals such as $\mathrm{FeSO}_{4} .7 \mathrm{H}_{2} \mathrm{O}$, hydrogen peroxide and hydrocloric acid. The operation cost for ozone is the electricity used for ozone generator. In 1 liter of wastewater, the operation cost for Fenton process is IDR. 256, whereas for ozonation, the operation cost is based on the electricity used for ozone production, which are $2 \mathrm{kwh}$, using middle industrial cluster, the tariff for electricity is IDR $1110 / \mathrm{kwh}$. Hence the operation cost is IDR 2220. Looking at the province regulation in the country (SK Gub. no 72 year 2013), which put the maximum of COD in wastewater can be disharged is $150 \mathrm{ppm}$, then we want to use both technology in 30 minutes time, which can result in remaining COD of $80 \mathrm{ppm}$ and $100 \mathrm{ppm}$ for Fenton and ozonation respectively. The operation cost for 30 minutes operation of $1 \mathrm{~L}$ wastewater will be IDR 128 and IDR 1110 for Fenton and ozonation consecutively. Consider the timelength used for experiment, Fenton process just need 15 minutes to degrade COD in wastewater at level below stated in the regulation, while ozonation needs 30 minutes to achieve the requirement level of COD in wastewater by the same regulation. Hence, it is obvious that the operation cost of Fenton's reagent is cheaper than that in ozonation.

\section{CONCLUSION}

This study investigated the COD removal in yarn dyed wastewater using Advanced Oxidation Procesess, Fenton's reagent and ozonation. It is apparent that Fenton process is more favor to ozonation, both in the ability on removal efficiency and economic feasibility. The overall removal efficiency using Fenton's reagent and ozonation were $86.2 \%$ and $83.06 \%$ respectively. The initial $\mathrm{pH}$ of wastewater was favor for $\mathrm{pH} 3.0$ and 7.0 in Fenton process and ozonation respectively. The first two minutes of Fenton process was spontaneous since the removal efficiency was $68.3 \%$ and the first 10 minutes of ozonation give $63.07 \%$ removal. There is only 15 and 30 minutes needed for Fenton process and ozonation to achieve the allowable of COD in wastewater to be discharged, the COD removal for 15 minutes in Fenton process and 30 minutes in ozonation were $84.8 \%$ and $81 \%$ respectively. The operation cost of Fenton process was almost one-tenth compare to ozonation.

\section{ACKNOWLEDGEMENT}

This research was financially supported by a research grant from Higher Education and Research Ministry under a scheme of PUPT 2016.

\section{DAFTAR PUSTAKA}

APHA, (1998), Standard Methods for the Examination of Water and Wastewater, $20^{\text {th }} \mathrm{ed}$.

Baban, A., Yediler, A., Lienert, D., Kemerder, N., and Kettrup, A., (2003), Ozonation of High Strength Segregated Effluents from a Woolen Textile Dyeing and Finishing Plant, Dyes Pigments, 58, pp. 93-98.

Ensing, B., Buda, F., and Baerends, E.J., (2003), Fenton-like Chemistry in Water: Oxidation Catalysis by $\mathrm{Fe}(\mathrm{III})$ and $\mathrm{H}_{2} \mathrm{O}_{2}$, J. Phys. Chem. 107(A), pp. 5722- 5731 .

Fassi, S., Djebbar, K., Bousnoubra, I., Chenini, H., and Sehill, T., (2014), Oxidation of Bromocresol 
Green by Different Advanced Oxidation Processes: Fenton, Fenton-like, photo-Fenton, photo-Fenton-like and Solar Light: Comparative Study, Desalin. Water Treatment, 52, pp. 4982-4989.

Georgiou, D., Melidis, P., Aivasidis, A., and Gimouhopoulos K., (2002), Degradation of AzoReactive Dyes by Ultraviolet Radiation in the Presence of Hydrogen Peroxide, Dyes Pigments, 52, pp. 69-78.

Gunten, U.V., (2003), Ozonation of Drinking Water: Part I. Oxidation Kinetics and Product Formation, Water Res, 37(7), pp. 1443-1467.

Kadirelu, K., Kavipriya, M., Karthika, C., Radhika, M., Vennilamani, N., and Pattabhi, S., (2003), Utilization of Various Agricultural Wastes for Activated Carbon Preparation, and Application for the Removal of Dyes and Metal Ions from Aqueous Solutions, Bioresour. Technol, 87 (1), pp. 129-132.

Khataee, A.R, Vatanpour, V., and Amani Ghadim, A.R., (2009), Decolorization of C.I. Acid Blue 9 Solution by UV/Nano-TiO 2 , Fenton, Fenton-like, electro-Fenton and Electrocoagulation Processes: A Comparative Study, Journal of Hazardous Materials, 161, pp. 1225-1233.

Modirshahla, N., Behnajady, M.A., and Ghanbary, F., (2007), Decolorization and mineralization of C.I Acid Yellow 23 by Fenton and photo-Fenton Processes, Dyes and Pigments, 73, pp. 305-310.
Peleg, M., (1976), The Chemistry of Ozone in the Treatment of Water, Water Research, 10(5), pp. 361365

Qiao, R.P., Li, N., Qi, X.H., Wang, Q.S., and Zhuang. Y.Y., (2005), Degradation of Microcystin-RR by UV Radiation in the Presence of Hydrogen Peroxide, Toxicon, 45, pp.745-752.

Riadi, L., Sapei, L., Lidiawati, T., and Agustin, Y.E., (2016), Application of a Hybrid ElectrocoagulationFenton Process in Yarn Dye Wastewater: Kinetic Study, International Conference on Chemical Engineering, Bandung, Indonesia, pp. 1-5.

Selcuk, H., (2005), Decolorization and Detoxification of Textile Wastewater by Ozonation and Coagulation Processes, Dyes and Pigments, 64, pp. 217-222.

Tarr, M.A., (2003), Fenton and Modified Fenton Methods for Pollutant Degradation, in Chemical Degradation Methods for wastes and Pollutants, edited by Matthew A.Tarr (Marcell Dekker Inc,New York), pp. 165-178.

Wang, N., Zheng, T., Zhang, G., Wang, P., (2016), A Review on Fenton-like Processes for Organic Wastewater Treatment, Journal of Environmental Chemical Engineering, 4, pp. 762-787.

Zaied, M., Chutet, E., Puelon, S., Bellakhal, N., Desmazieres, B., Dacharoui, M., and Chaussee, A., (2011), Spontaneous Oxidative Degradation of Indigo Carmine Thin Films Bernessite Electrodeposited onto $\mathrm{SnO}_{2}$, Appl.Catal B., 107 (1-2), pp. 42-51. 